\title{
What's in a name: Ethnophobic Terms as Key to English Speaker's Conceptualisation of Arabs
}

\author{
V.V. Orlova \\ National Taras Shevchenko University of Kyiv \\ Corresponding author. Email: velena1@ukr.net
}

Paper received 29.01.21; Accepted for publication 12.02.21.

\begin{abstract}
https://doi.org/10.31174/SEND-Ph2021-248IX73-16
\end{abstract}
\begin{abstract}
The article explores ethnic slurs used in Modern English that denote Arabs. The research reveals significant simplification of this category: in the naïve language picture of the world, "Arabs" are conceptualised both as an ethnic and a racial group. The analysis of ethnophobic terms uncovers a variety of sources to coin new lexemes to refer to Arabs that include words formed with English morphemes as well as borrowings from Arabic. The imagery of the sample provides with the evidence that English speakers are familiar with Arab culture primarily through mass media exposure.
\end{abstract}

Keywords: ethnic slur, language picture of the world, conceptualisation, categorisation, culture.

Introduction. Until the 2020 coronavirus pandemic, the world was quite penetrable and cross-cultural communication flourished in all imaginable forms facilitated by virtual space without almost any borders (except those introduced by so-called "totalitarian" states) and real travelling that was relatively easy. As a result, migration was one of the features of the world demography and multiculturalism came to be recognized as a fact true for most, if not all, English-speaking states. Though mixing people, worldviews and ideas promises great breakthroughs and insights in science and culture, the exposure to differences also breeds prejudice, xenophobia and racism that may in the long run lead to ethnic conflicts and tension within a multicultural society as well as between states.

Racist ideologies and discrimination are inevitably expressed in language, so examining race discrimination through its verbalization helps to better understand what causes interracial tension and xenophobia as well as to find ways to ease these destructive social phenomena. Ethnic slurs are those language means that provide researchers with a chance to look at an ethnic group or a race "through their haters' eyes" because it is usually quite easy to get to the core of the motivation that underlies insulting coinages.

Literature review. The research assumes the anthropocentric nature of language, which was first put forward by Wilhelm von Humboldt in the early $19^{\text {th }}$ century and developed by Claude Lévi-Strauss, Franz Boas, Edward Sapir, Benjamin Whorf, Anna Wierzbicka, etc. (see, for example $[3 ; 4 ; 10 ; 15 ; 17])$. The anthropocentric paradigm in linguistics has laid the foundation for modern cognitive and cultural linguistics that explore pictures of the world as they are verbalized in different languages $[2 ; 17 ; 14]$.

Ethnic slurs (also knows and ethnophobic terms and ethnophaulisms) belong to the set of ethnonyms, i.e., names used to refer to an ethnic group, nation, tribe or people [25]. From the point of view of stylistics, ethnonyms may be divided into two groups:

1) stylistically neutral lexemes and

2) stylistically marked lexemes that typically classified as slang and point out some peculiarity of the nominated ethnic group.

It is stylistically marked ethnonyms that make up ethnic slurs (or ethnophaulisms) "typically utilizing the caricature of some identifiable feature of the group being derided, often physical features" [20]. It should be borne in mind that stylistic colouring or stylistic neutrality are not permanent qualities: stylistic meanings of words may veer throughout the history of a language. This happened, for example, to the words black, colored and AfroAmerican at different stages in American English. Black and colored were neutral, then moved to politically incorrect vocabulary, yet nowadays, when race awareness and race identity are gaining in importance and start outweighing the universalist ideology, these lexemes have become acceptable and even preferable, which is supported by the very name of the anti-discrimination movement Black Lives Matter.

The research into ethnic slurs is carried out by a number of linguists such as Antonchenko [1], Gorshunova [7], Honta [5; 6], Kennedy [23], Kushch [9], Liashenko [13], Mullen [26; 27], Skidanova [16], Tsebrovskaya [18], etc. The scholars look into various aspects of ethnophobic terms, starting from their purely linguistic features (morphology and word forming patterns) up to their cognitive, cultural peculiarities and communicative value. Thus, exploring structural and semantic features of ethnophaulisms gives an insight into their motivation and tendencies of semantic change as well as facilitates classifying them into groups according to their morphology. Studying ethnic slurs from the point of view of cultural linguistics sheds light onto social phenomena that conditioned these coinages as well as onto the picture of the world and stereotypes typical of speakers who coin these words.

The objective of the research is to study ethnic slurs that function in modern English to refer to representatives of the Arab ethnicity in order to uncover those components that make the referent "identifiable" for Englishspeaking communities and, as a result, identify English speakers' "cultural assumptions" and "background knowledge" about Arabs and their culture.

Material and methods. The sample is made up of 62 ethnic slurs that are defined in the sources as words referring to Arabs. The material was selected by means of continuous sampling from the two online databases, List of Ethnic Slurs [24] and Racial Slur Database [28], and two online dictionaries [25;31].

The further research involved such methods as descriptive analysis, conceptual analysis, componential analysis, and etymological analysis. 
Results and discussion. It should be noted that even a quick look at the sample is enough to see that ethnic slurs verbalize naïve perception of the 'Arab category'.

First, the research has uncovered the lack of clear differentiation between the notions of 'race' and 'ethnicity' (which is obvious even in the names of the sources that imply viewing Arabs both as a race and as an ethnicity), though they seem to be quite distinct in sociological studies. 'Race' refers "to a category of people who share certain inherited physical characteristics, such as skin color, facial features, and stature" [19, p.331]. Hence, race draws on biological peculiarities. Ethnicity, in its turn, is based on "shared social, cultural, and historical experiences... that make subgroups of a population different from one another. ... an ethnic group is a subgroup... with a set of shared social, cultural, and historical experiences; with relatively distinctive beliefs, values, and behaviors" [19, p.334-335]. 'Race' and 'ethnicity' are interrelated indeed and they are both relevant when applied to the material from the sample.

As we will see, for naïve consciousness, people's physical features (e.g., skin colour) are as relevant as their cultural features (e.g., clothes or culinary preferences) if one needs to refer these people to an ethnic group. In case with Arabs, representatives of this group may be quite diverse both in terms of their physical features (e.g., Arabs from Sudan look different from Lebanese Arabs) and in terms of their cultural habits such as food, clothes, etc. The matter gets even more complicated because, for the average English speaker, the 'Arab category' correlates with Muslims that make up a religious group, but, since Islam is one of the world religions, not all Muslims are Arabs just like not all Arabs are Muslims. As a result, ethnic slurs for 'Arabs' expose how naïve consciousness handles the complex social reality and manages to categorize complicated phenomena.

The ethnic slurs to denote Arabs may be divided into several groups.

1. Some lexemes are slang modifications of stylistically neutral words, e.g., $R a b$ (a clipped word from $A r$ $a b)$, Bara (Arab only read backwards), Naffer (a blending of North African, which distorts the reality because Iraq, Lebanon and Syria are Arab states located in Western Asia).

2. Some lexemes point out the skin colour, e.g., demi-nigger, double D (desert darky), mocha, off-white, peanut butter brother. The words reveal an obviously racist ideology that categorizes people into two groups, namely the white and the black. Viewed from this perspective, Arabs are intermediate between the two. It should be noted here that the lexeme nigger has definitely undergone a semantic change. It originates from the Spanish negro to refer to the black colour, yet nigger possesses a remarkable word building capacity that has transformed this lexeme into a politically incorrect morpheme similar to man in policeman. While in such ethnic slurs as farm nigger, field nigger and house nigger the second part means 'a black person', there are such ethnic slurs as rice nigger and squint nigger to refer to Asians, taco-nigger and river nigger to refer to Mexicans and salmon nigger and tundra nigger to denote Native Americans. These coinages cannot but show that nigger in these cases has nothing to do with a skin colour but rather means 'a representative of a despised non-white ethnic group'.

3. A number of ethnic slurs have appeared to refer to the assumed connection between Arabs and terrorism. These stereotypes became particularly strong in the USA and the West in general after the attack on the World Trade Centre in 2001 and a number of suicide bombings. The ethnic slurs based on these references are created with antonomasia, e.g., Atta (the first name of the 9/11 terrorist who flew a plane into the World Trade Centre) and Bin Laden (also Osama), a founder of al-Qaeda; there is a borrowing from Arabic (Jihad) as well as compounds (Bomb Builder, Firecracker, and Land Torpedo). Here also belongs the ethnophaulism cave nigger that refers to Osama bin Laden, who allegedly was hiding in Tora Bora cave complex in Afghanistan.

4. Arab culture has interfered to a certain extent into English-speaking communicative space, since the sample contains 24 lexemes to denote Arabs that draw on the average English speaker's knowledge about the culture of this ethnic group and the average Westerner's idea of the Arab world in general. Here belong

- $\quad$ proper nouns Abdul, Fadi and Muhammad used as ethnic slurs to refer to a man who looks like an Arab. Habibi, an Arabic word used as a friendly form to address a man, also functions as an ethnophaulism. Another Arab lexeme, borrowed into English and used to refer to an Arab male, is Hajji/Hadji/Haji, yet while in English the meaning of the word is pejorative, in Arabic, hajji is a honorific used to address a man who has completed the pilgrimage to Mecca. Interestingly, the sample does not contain any female name to refer to an Arab female, though there are proper female names to address women from some other ethnic groups (for example, Natasha and Guidette). Another noun, Alphabet, which is a regular English word, may mean 'an Arab' due to its phonetic similarity with the Arabic language: the first syllable al resembles the Arabic article;

- $\quad$ proper nouns Aladdin and Ali Baba, the characters' names from the famous Arabic fairy tales, have been popularized by Western mass culture and Walt Disney Pictures in particular and started to refer to members of the ethnic group. The ethophaulisms carpet pilot and rug rider also originate from the fairy tale about Aladdin and here it also was the film industry that contributed to their popularity;

- lexemes coined through a metonymic transfer: they depict Arabs as inhabitants of certain territories, e.g., Abi-Dabi (the distorted form of Abu-Dhabi, the capital of the United Arab Emirates). Most ethnic slurs, however, depict Arabs people from the desert, desert being verbalized metonymically through the sand component (sandy, sand monkey / moolie / nigger / rat / scratcher / snigger (a blend of 'sand' and 'nigger')) or dune (dune coon);

- $\quad$ ethnic slurs as Oil Baron and OPEC are based on the average speaker's idea of Arab states' economies, though only six out of 13 members of the OPEC are Arab states;

- $\quad$ ethnophaulism Mozzie/Muzzie, despite being a shortening of Muslim and categorizing a person as a member of the religious group, is defined in the database "Arabs" [28]. Ethnic slurs dirty knees and sand kisser used to refer to Arabs show that the English speaking 
community is also aware of the posture and gestures a Muslim makes while praying (i.e., kneeling and prostrating with the forehead, nose, knees, palms and toes touching the ground);

- $\quad$ ethnic slurs diaper head/rag head/towel head show that male Arabs are also recognized by English speakers for their traditional clothes (though turbans are also worn by Sikhs) when it comes to men. Specific clothes make Arab visible: their traditional dark shapeless garments have produced such ethnophaulisms as $B M O$ (abbreviation of 'black moving object') and Pajama Ma$m a$.

5. There are eleven ethnic slurs in the sample that are generated at the crossroads of several cultures: Arab culture and Western mass culture. Here belongs, for example, camel cowboy (a mix of two concepts: the former is the key one for the Arabian countries, while the latter is culturally important for the USA). Another ethophaulism, $A h a b$, appeared after the 1962 song by Ray Stevens Ahab the Arab that portrayed a sheik "of the burning sands" called Ahab [29]. Mass media products, films and TV in particular, have produced such 'cultural blends' as Batman used to refer to a veiled Arab woman dressed in black. Another film that has provided two new slang names for Arabs was Star Wars: the tribes of Jawas, completely hidden behind their robes and living in the deserts of Tatooine, and Ewoks, wearing headdresses that resemble those worn by religious Muslims, have lent their names to Arabs. In the 1990s, the US Saturday Night Live show introduced American audiences to Iraqi Pete, the character played by Adam Sandler. This character's name has become a common noun and got to refer not only to Iraqis or people of Iraqi descent but to all Arabs.

Conclusion. The analysis of English ethnic slurs used to denote Arabs reveals that the ethnophobic terms are coined with the means of the English language (English morphemes or phonemes), yet the sample also contains borrowings from Arabic. Conceptualisation of this ethnic group in naïve consciousness of English speakers lacks consistency in that it does not differentiate between race, ethnicity and religion and taps information and imagery from mass media and mass culture. The ethnophaulisms of the sample verbalize English speakers' ideas of typical 'Arab shape', 'Arab ways' and 'Arab faith' and ignore the diversity within each of these features.

\section{ЛІТЕРАТУРА}

1. Антонченко Т. М. Лінгвопрагматичні особливості функціонування етнонімів та етнофобізмів (на матеріалі американського варіанта англійської мови) // Вісник Київського лінгвістичного університету. Сер. Філологія. 1999. №1. C.95-103.

2. Арутюнова Н. Д. Язык и мир человека. М.: Языки русской культуры, 1999. 896 с.

3. Боас Ф. Методы этнологии // Антология исследований культуры. 1997. Т. 1. С.519-527.

4. Вежбицкая А. Язык. Культура. Познание. М.: Русские словари, 1996. $416 \mathrm{c.}$

5. Гонта I. А. Вербалізація екстралінгвістичної домінанти у мові (на матеріалі американського мовного субстрату) // Вісник Маріуполоського державного університету. Серія Філологія. 2018. Вип.19. С. 204-210.

6. Гонта I. А. Екстралінгвістичні чинники в утворенні етнофобізмів в американському мовному субстандарті // Науковий вісник Херсонського державного університету. Серія: Перекладознавство та міжкультурна комунікація. 2018. Вип. 1(2). С.31-35.

7. Горшунова Е. Ю. Этнические стереотипы, прозвища и ярлыки американских индейцев на основе антропологических характеристик // Известия Российского государственного педагогического университета им. А. И. Герцена. 2009. Вып. 90. С. 135-137

8. Гумбольдт В. фон. Избранные труды по языкознанию. М.: Прогресс, 2000. 400 с.

9. Кущ Е. О. Національно-культурна специфіка лінгвальної реалізації етнічних упереджень у Великобританії // Мова, мовлення, мовна комунікація. Матеріали VII Міжнародної науково-практичної конференції «Наука і освіта 2004». Серія: Філологічні науки. 2004. Том 26. С. 49-51.

10. Леви-Стросс К. Структурная антропология [пер. С фр., под ред. и с прим. В. В. Иванова]. М.: Главная редакция восточной литературы, 1985. $396 \mathrm{c}$.

11. Левицький А. Е., Святюк Ю. В. Етнономінації у дзеркалі міжкультурної комунікації. К.: Логос, 2010. 192с.

12. Литовченко Д. Аспекти стереотипізації мусульман у медіа джерелах Сполученого Королівства Великобританії та Північної Ірландії // Мовні та концептуальні картини світу. 2017. Вип. 59. С. 140-148

13. Ляшенко И. В. Языковая сущность и прагматические

функции этнических прозвищ (на материале английского языка) : дис. ... канд.филол.наук: 10.02.04 // Пятигорский государственный лингвистический университет, Пятигорск, 2002. 208 с.

14. Святюк Ю. В., Петровський М. В., Рубан Л. М. Лінгвокогнітивний аспект категоризації етнічних груп у англійській мові // Наукові записки міжнародного гуманітарного університету. 2019. Вип.30. С.45-56

15. Сепир Э. Избранные труды по языкознанию и культурологии. М.: Прогресс, 1993. 656 с.

16. Скіданова К. Ю. Структурні характеристики англійських етнофобізмів // Актуальні проблеми філології та перекладознавства. 2009. Вип. 4. С. 197-200.

17. Уорф Б. Л. Отношение норм поведения и мышления к языку // Новое в лингвистике. 1960. Вып. 1. С. 135-168.

18. Цебровская Т.А. Структурно-семантические и этнолингвистические характеристики дерогативно маркированных этнонимов современного английского языка : Дис. ... канд.филол. наук: 10.02.04 // Крымский федеральный университет имени В.И.Вернадского, Симферополь, 2016. -206 c.

19. Barkman S. E. Sociology: Understanding and changing the social world. Minneapolis: University of Minnesota Libraries Publishing. 2016. -815 p.

20. Definitions. Mode of access: https://www.definitions.net/definition/ETHNOPHAULISM

21. Henderson A. "What's in a Slur?" // American Speech. 2003. Vol. 78 (1). P. 52-74.

22. Honta I., Pastushenko T., Borysenko N. Colour component in the semantics of ethnophobic terms (the case of nonstandard American English) // Advanced Education. 2019. Vol.12. P. 226-235.

23. Kennedy R. Nigger: The Strange Career of a Troublesome Word. NY: Pantheon, 2002. 258 p.

24. List of ethnic slurs // Wikipedia Mode of access: https://en.wikipedia.org/wiki/List_of_ethnic_slurs_by_ethnici ty

25. Merriam-Webster Dictionary. Mode of access: https://www.merriam-webster.com/dictionary/ethnonym

26. Mullen B. Ethnophaulisms and exclusion: The behavioral consequences of cognitive representation of ethnic immigrant groups // Personality and Social Psychology Bulletin. 2015. 
№ 31. P. 1056-1067

27. Mullen B. Ethnophaulisms for ethnic immigrant groups // Journal of Social Issues. 2011. Vol. 57. P. 457-475

28. Racial Slur Database. Mode of access: http://www.rsdb.org

29. Stevens, R. Ahab The Arab [Music Video] [from Get Serious]. $\quad$ Retrieved from https://www.youtube.com/watch?v=tYn_6NjcopY

30. Sviatiuk Yu. National stereotypes in phraseological units with ethnic names // Studia Slawistyczne. Etnolingwistyka i komunikacja miedzykulturowa. Lublin: Wydawnictwo KUL, 2017. P. 59-67.

31. Urban Dictionary. Mode of access: https://www.urbandictionary.com/define.php?term=The $\% 20$ Urban\%20Dictionary

32. Wierzbicka A. Semantics: Primes and Universals. Oxford University Press, 1996. 402 p.

\section{REFERENCES}

1. Antonchenko T. M. Linguopragmatic peculiarities of functions performed by ethnonyms and ethnophobic terms (based on American English) // Visnyk Kyyvskoho lingvistychnoho universytetu. Seria: Philology. 1999. \#1. P. 95-103.

2. Arutiunova N. D. Language and World of the Human. Moscow: Yazyki russkoi kultury, 1999. $896 \mathrm{p}$.

3. Boas F. Methods of Ethnology // Antologia issledovanii kultury. 1997. Vol. 1. P. 519-527.

4. Wierzbicka A. Semantics, Culture, and Cognition. Moscow: Russkie slovari, 1996. 416 p.

5. Honta I. A. Verbalization of extralinguistic dominant in the language (on the material of the American English substandard) // Visnyk Mariupolskoho derzhavnoho universytetu. Seria: Philology. 2018. Vol. 19. P. 204-210.

6. Honta I. A. Extralinguistic factors in the formation of ethnophobisms in the American English substandard // Naukovyi visnyk Khersonskoho derzhavnoho universytetu. Seria: Translation Studies and Cross-Cultural Communication. 2018. Vol. 1(2). C. 31-35.

7. Gorshunova Ye. Yu. Ethnic stereotypes, nicknames and labels of Native Americans on the basis of their anthropological features // Izvestiya Rossiyskogo gosudarstvennogo pedagogicheskogo universiteta im. A.I. Gertsena. 2009. Is. 90. P. 135137

8. Humboldt W. von. Selected Writings in Linguistics. Moscow: Progress, 2000. 400 p.

9. Kushch E. O. National and cultural specificity of lingual actualization of ethnic prejudice in Great Britain // Mova, movlennia, movna kommunikatsia. Papers of the $7^{\text {th }}$ theoretical and practical conference "Science and Education 2004". Seria: Philological sciences. 2004. Vol. 26. P. 49-51.
10. Lévi-Strauss C. Structural Anthropology [trans. from French, ed. And commentary by V. V. Ivanov]. Moscow: Glavnaia redaktsia literatury, $1985.396 \mathrm{p}$.

11. Levitsky A. E., Sviatiuk Yu. V. Ethnonominations in crosscultural communication. K.: Logos, 2010. 192 p.

12. Lytovchenko D. Aspects of Muslim stereotyping in the media of Great Britain and Northern Ireland // Movni ta kontseptualni kartyny svitu. 2017. Is. 59. P. 140-148

13. Liashenko I. V. Linguistic nature and pragmatic functions of ethnic nicknames (on the material of the English language): Thesis for a candidate Degree in Philology: 10.02.04 // Piatigorsky gosudarstvenny lingvistichesky universitet, Piatigorsk, 2002. 208 p.

14. Sviatiuk Yu. V., Petrovsky M. V., Ruban L. M. Linguocognitive aspect of ethnic group categorisation in English // Naukovi zapyski mizhnarodnoho humanitarnoho universytetu. 2019. Is. 30. P.45-56

15. Sapir E. Selected Writings in Linguistics and Culture. Moscow: Progress, 1993. 656 p.

16. Skidanova K. Yu. Structural features of English ethnophobic terms // Aktualni problem filolohii ta perekladoznavstva. 2009. Is. 4. P. 197-200.

17. Whorf B. L. The relation of habitual thought and behavior to language // Novoie v lingvistike. 1960. Is. 1. P. 135-168.

18. Tsebrovskaya T. A. Structural-semantic and ethnolinguistic characteristics of derogatorily marked ethnonyms in Modern English: Thesis for a candidate Degree in Philology: 10.02.04 // Krymsky federalny universitet imeni B. I. Bernadskogo, Simferopol, 2016. 206 p. 